УДК 340.15

DOI https://doi.org/10.32836/2521-6473.2021-1.26

\title{
Д. А. Шевченко
}

К.ю.н.

Харківського національного університету внутрішніх справ

\section{ТРАНСФОРМАЦІЯ ІНСТИТУТУ МАЙНОВИХ ВІДНОСИН ПОДРУЖЖЯ ЗА РАДЯНСЬКИМ ЗАКОНОДАВСТВОМ}

\begin{abstract}
Наукова стаття присвячена дослідженню та комплексному аналізу трансформаиії інституту майнових відносин подружжя за радянським законодавством.

3 урахуванням доктринального дослідження констатовано, що держсва строго відстежувала сімейні взаємини і залишала за собою право втручання в них, пери за все на захист інтересів дітей. Зокрема, батьки могли бути позбавлені батьківських прав не тільки якщо вони ухилялися від виконання свойх обов'язків по вихованню дітей або зловживали своїми батьківськими правами, жорстоко поводилися з дітьми, були хронічними алкоголіками або наркоманами, а й якщо батьки надавали шкідливий вплив на дітей своєю аморальною, антигромадською (зрозуміло, з точки зору норм комуністичної моралі) поведінкою. У той же час особливості економічної ситуації в країні, накопичений судовою практикою досвід приводили до необхідності внесення в правові норми певних змін, щэо доповнювали прогалини або конкретизували окремі норми законодавства, що регулюють сімейні правовідносини.

Ключові слова: шлюб, сім'я, шлюбно-сімейні відносини, сімейні правовідносини, подружжя, майнові права подружжя, немайнові права подружжя, майнові відносини подружжя.
\end{abstract}

\section{Shevchenko D. A. Transformation of the institute of property relations of spouse under soviet legislation}

The scientific article is devoted to the research and complex analysis of the transformation of the institution of property relations of spouses under Soviet law.

Taking into account the doctrinal study, it was stated that the state strictly monitored family relationships and reserved the right to intervene in them, primarily to protect the interests of children. In particular, parents could be deprived of parental rights not only if they evaded their parenting responsibilities or abused their parental rights, abused their children, were chronic alcoholics or drug addicts, but also if parents harmed their children by their immoral, anti-social (of course, in terms of communist morality) behavior. At the same time, the peculiarities of the economic situation in the country, the experience gained by judicial practice led to the need to make certain changes in the legal norms, which supplemented the gaps or specified certain rules of law governing family relations.

Key words: marriage, family, marital and family relations, family legal relations, spouses, property rights of spouses, non-property rights of spouses, property relations of spouses.

Постановка проблеми. Сім'я є первинним соціальним осередком і джерелом відтворення соціуму, яке постає в якості виховного середовища в рамках якого формуються і закріплюються на побутовому рівні світоглядні, культурологічні та моральні основи життедіяльності суспільства. Актуальність проблем регулювання шлюбно-сімейних відносин і гострота питань, пов'язаних з ними, особливо помітні в нашій країні в умовах значних показників у депопуляції населення, а також, зростання кількості шлюборозлучних процесів, збільшення числа позашлюбних дітей та дітей-сиріт і позбавлених батьківського піклування.

Стан дослідження. Проблематика пов'язана із дослідженням правових засад шлюбно-сімейних відносин привертала увага багатьох вітчизняних науковців, зокрема такими вченими як: О. Л. Копиленко, Кудін С. В., П. П. Музиченко, Н. М. Онищенко, В. І. Озель, В. В. Россіхін,. В той же час, не дивлячись на сталий науковий інтерес до вказаної проблематики, дослідження та комплексний трансформації інституту майнових відносин подружжя за радянським законодавством належить до малодосліджених тем.

Внаслідок чого, метою даної статі є дослідження та комплексний аналіз трансформації інституту майнових відносин подружжя за радянським законодавством.

Виклад основного матеріалу. Жовтнева революція 1917 року стала не тільки поворотним етапом в історії, що визначив весь подальший розвиток нашої країни, але і поворотним пунктом в регулюванні сімейних відносин, що ознаменував початок формування абсолютно-нового сімейного права, принципово-відмінного в своїх підходах до вирішення проблем шлюбу і сім'ї від сімейного права країн Заходу і не мав на той період аналогів в світовій практиці. Очевидно, що після революції, встановлення нового економічного ладу, кардинальної зміни менталітету суспільства - сімейне законодавство не могло не зазнати змін. Сфера сімейного права була однією з перших, де було здійснено законодавче унормування, i це природно, адже оскільки сім'я - осередок суспільства і при перебудові останнього обов'язково піддається впливу [1, с. 351$]$.

\section{(ㄷ. Д. А. Шевченко, 2021}


Одним з основних завдань радянської влади була зміна сформованого типу сім'ї, що була основою колишнього ладу, і побудови шлюбно-сімейних відносин на принципово-нових засадах відповідно до нової державної ідеології. Колишні принципи правового регулювання шлюбу і сім'ї, засновані на християнській релігійній доктрині, поступалися місцем новим принципам, заснованим на концепції абсолютної рівності прав чоловіків і жінок. В першу чергу необхідно було знищити вплив релігійних установ на шлюбно-сімейні відносини, вирішити питання про свободу укладення і розірвання шлюбів, законодавчо надати жінкам рівні права з чоловіками, зрівняти становище дітей, народжених у шлюбі та поза шлюбом. Рішення назрілих ще в епоху Російської імперії проблем в сфері шлюбу і сім'ї дозволили б ще незміцнілій радянській владі залучити на свою сторону симпатії значної кількості населення. Крім того, введення світської концепції шлюбу вирішувало ще одну серйозну проблему, яка могла ускладнити процес зміцнення влади в країні - опір церкви як одного з найважливіших оплотів самодержавства. Виведення питань шлюбу і сім'ї з-під іiі юрисдикцією сильно знижувало вплив духовенства на населення.

Майже відразу ж після Жовтневої революції 1917 р були проведені дві найважливіші реформи сімейного законодавства. Вони були оформлені декретами Ради Народних Комісарів Української РСР в області сімейного права «Про громадянський шлюб, про дітей і про ведення книг актів стану» від 18 грудня 1917 (далі - «Декрет про цивільний шлюб») і «Про розірвання шлюбу» від 19 грудня 1917 року [2, с. 23].

Декрет про цивільний шлюб скасовував обов'язковий порядок укладення шлюбу в церковному порядку і робив його особистою справою наречених, а укладання шлюбу за релігійним обрядом не породжувало правових наслідків. Сдиною формою шлюбу для всіх громадян незалежно від віросповідання був визнаний шлюб, укладений у державних органах. За шлюбами, укладеними в церковному порядку до введення в дію цього декрету, зберігалася юридична сила і вони не вимагали переоформлення, причому, значно полегшені були умови вступу в шлюб. Згідно ст. 2 Декрету про цивільний шлюб, безумовно заборонено було одружуватися особам, які не досягли шлюбного віку (для чоловіків - 18 і для жінок - 16 років), родичам по прямій лінії, рідними та братів і сестер, особам, які перебувають у шлюбі, і божевільним. Всі інші обставини не мали значення.

На слушне міркування А. Г. Гойхбарга: «пролетаріат міг би відмовитися і від формальних посвідчень шлюбу, надавши справу оформлення шлюбу на розсуд осіб, що вступають в шлюб між собою, але .... зробити це безпосередньо після того, як панував виключно релігійний, церковний шлюб, означало б залишити все по старому, надати населення до влади духовенства. Тому, головним чином, з метою боротьби 3 релігією і духівництвом, пролетарська влада заявила, що шлюб, оформлений в церкві, тільки перед духовенством, вона не стане визнавати і ніяких наслідків 3 таким шлюбом, 3 такою його формою не стане пов'язувати, що вона стане визнавати тільки шлюб, здійснений ні перед особою священика або взагалі представника духовенства, а тільки перед обличчям радянського службовця [3, с. 99].

Декрет про цивільний шлюб зрівняв в правах дітей, народжених у шлюбі та поза ним. Доля позашлюбного потомства перестала бути переважно турботою однієї жінки. Відтак, було дозволено визнавати батьківство в судовому порядку в разі, якщо батько добровільно не подавав відповідну заяву до відділу записів шлюбів і народжень за місцем знаходження матері. При вступі в шлюб особам надавалось вільно визначати чи будуть вони надалі іменуватися прізвищем чоловіка або дружини або з'єднанням прізвищ. На посвідчення події шлюбу, молодим видається копія свідоцтва про одруження. Це нововведення для свого часу було революційним, а єдине прізвище для сім'ї було своєрідним символом єднання подружжя і єдності сім'ї. Одночасно це було «символом влади чоловіка, символом приналежності дружини чоловікові, символом того, що фігура чоловіка в правовому відношенні як би затуляє фігуру дружини» [4, с. 99]. Визнання за жінкою під час вирішення питання про вибір прізвища рівних прав з їі чоловіком, право на вибір в якості загальної прізвища родини - прізвища дружини, означав фактично законодавче фіксування остаточного розриву зі старою традицією місця чоловіка в сім'ї та зрівнювання жінки в правах з чоловіком.

Другим найважливішим декретом в сфері сімейного права став Декрет «Про розірвання шлюбу». На його підставі процес розлучення подружжя було значно полегшений, оскільки були скасовані всі колишні підстави до розірвання шлюбу. Справи про розлучення було вилучено з відання духовних консисторій та інших установ як православного, так і інших релігійних культів, і передані на розгляд до місцевих судів. Для розлучення подружжя за взаємною згодою взагалі був передбачений позасудовий порядок. Заява про розірвання шлюбу за взаємною згодою подавалася безпосередньо до відділу записів шлюбів, в якому зберігалася запис про укладення даного шлюбу. Просити про розірвання шлюбу могли як обоє одночасно, так і будь-який з них. Прізвище розлученого подружжя визначалося за їх згодою, а в разі відсутності згоди 3 цього питання кожному присвоювалась своє, водночас прізвище ж дітей, як і те, з ким із батьків залишаються діти, визначалася судом. Тим самим можливість розлучення стала легкою, однаково доступною як чоловікам, так жінкам, і залежала тільки від власного бажання осіб, які перебували в шлюбі. Свобода розлучення, введена цим декретом, безумовно, стала тим фактором, який реально забезпечував зміцнення незалежного положення жінки в сім’ї. Шлюб з священного нерозривного союзу перетворювався в добровільний тимчасовий союз двох вільних людей.

Оскільки зазначені вище декрети були прийняті в революційну епоху повалення старого ладу, зрозуміло, вони не могли охопити всі сторони життя сім'ї, вирішивши тільки найболючіші питання. Декрет 
«Про громадянський шлюб, про дітей і про ведення книг актів стану» майнових аспектів взагалі ніяк не торкався, залишаючи в силі діючий і раніше порядок. Встановивши вільне розірвання шлюбу, без з'ясування причин і мотивів розпаду сім'ї, за бажанням будь-якого з подружжя Декрет «Про розірвання шлюбу» регламентував тільки питання про надання утримання розведеній дружині і дітям. Відтак, закріплювалося, що в разі угоди про те подружжя, суддя, одночасно з постановою про розірвання шлюбу, визначав, у кого з батьків залишаються під опікою неповнолітні діти, і хто з подружжя і в якій мірі повинен нести витрати по утриманню та вихованню дітей, так само як і про те, чи зобов'язаний чоловік і в якому розмірі здійснювати утримання дружини, тобто в разі досягнення подружжям добровільної згоди з приводу виховання і утримання дітей і дружини, суддя фактично тільки стверджував своїм рішенням їх угоду, надаючи їй юридичну силу. В іншому випадку, якщо домовленість не була досягнута, ці питання вирішувалися загально позовним порядком в місцевому суді. При цьому суддя, негайно ухваливши рішення про розірвання шлюбу, визначав тимчасово, до вирішення спору, долю дітей і питання про тимчасове утримання дітей і дружини, якщо вона того потребувала [5, с. 64].

Перший радянський окремий кодифікований законодавчий нормативно-правовий акт у галузі сімейного права - Кодекс законів про акти громадянського стану, шлюбне, сімейне і опікунське право було прийнято 22 жовтня 1918 року, який згодом став основою для Кодексу законів про родину, опіку, шлюб і про акти громадянського стану УРСР 1926 року. Цікаво, що якщо першими декретами були порушені тільки деякі аспекти сімейних відносин, то за результатами проведення систематизації були врегульовані повністю всі найважливіші питання у сфері шлюбно-сімейних відносин. Відтак, формально було вперше законодавчо закріплено рівність чоловіка і жінки. Вкотре наголошувалось, що правові наслідки породжував тільки цивільний (світський) шлюб, зареєстрований в органі реєстрації актів цивільного стану, тоді як за шлюби, укладені за релігійним обрядом, не мали ніякої юридичної сили і не породжували правових наслідків. Така пильна увага до форми укладення шлюбу, серед іншого була викликана тим, що переважна частина населення країни була віруючою, а, значить, з точки зору більшовиків, церква все ще, навіть будучи відокремленою від держави, представляла потужну політичну силу і небезпеку для нової влади, 3 якої необхідно боротися в усіх напрямках, включаючи руйнування усталених релігійних уявлень про шлюб та сім'ю. Причому, навіть на законодавчому рівні прямо вказувалось, що на відміну від законодавства Російської імперії, різновірність подружжя не перешкоджає укладенню шлюбу, дозволяється одружуватися і ченцям, які перебувають в ієрейську або дияконському сані, чи особам, які дали обітницю безшлюбності - зазначені правила йдуть врозріз з вимогами релігійних норм та були включені в тексти нормативних актів 3 метою остаточного приниження ролі церкви в житті громадян.

Висновок. Таким чином, можна зробити висновок, що держава строго відстежувала сімейні взаємини і залишала за собою право втручання в них, перш за все на захист інтересів дітей. Зокрема, батьки могли бути позбавлені батьківських прав не тільки якщо вони ухилялися від виконання своїх обов'язків по вихованню дітей або зловживали своїми батьківськими правами, жорстоко поводилися з дітьми, були хронічними алкоголіками або наркоманами, а й якщо батьки надавали шкідливий вплив на дітей своєю аморальною, антигромадською (зрозуміло, з точки зору норм комуністичної моралі) поведінкою. У той же час особливості економічної ситуації в країні, накопичений судовою практикою досвід приводили до необхідності внесення в правові норми певних змін, що доповнювали прогалини або конкретизували окремі норми законодавства, що регулюють сімейні правовідносини.

\section{Список використаних джерел:}

1. Исаев И. А. История государства и права России. Москва : Юристъ, 2004. 797 с.

2. Камінський В. Парубоцькі громади на Поділлі як звичаєво-правовий інститут. Праці для виучування звичаєвого права України. Київ, 1928. С. 88 - 106.

3. Гойхбарг А. Г. Брачное, семейное и опекунское право Советской республики. Москва : Гос. изд-во, 1920. 164 c.

4. Ворожейкин Е. М. Семейные правоотношения в СССР. Москва : Юрид. лит., 1972. 336 с.

5. Антокольская М. В. Семейное право: учебник. Москва : Юристь, 2002. 336 с. 